\title{
HUBUNGAN BEBAN KERJA DENGAN STRES KERJA PADA PERAWAT DI RUANG ICU RSUD dr. H. MOH. ANWAR SUMENEP
}

Sugesti Aliftitah, Program Studi Profesi Ners Fakultas Ilmu Kesehatan

E-mail: purples_lovers@yahoo.co.id

Elyk Dwi Mumpuningtias, Program Studi Imu Keperawatan Fakultas Imu Kesehatan

Email: elikdwi@wiraraja.ac.id

Imam Muttaqin, Mahasiswa Program Studi IImu Keperawatan Fakultas IImu Kesehatan

E-mail: Imamajah305@gmail.com

\section{ABSTRACT}

Stress is an excessive workload, feelings of distress and emotional tension that impedes individual performance. The nurses' work stress can be attributed to the nurse's primary duties and responsibilities, heavy workloads, and leadership types.

This type of research was analytic with Cross Sectional research design. In this research, the independent variables are workload and the dependent variable is the nurses' work stress. One month research time in ICU Room dr. H. Moh. Anwar Sumenep, sample17 respondents with total population sampling technique. Questionnaire research instrument and observation sheet, data analysis using Spearman with a $(0,05)$.

The results of most of the workload of nurses were moderate $9(52,9 \%)$. Most of the work stress of nurse is light $10(58,8 \%)$. The data analysis obtained $p$ value $(0,031)<\alpha(0,05)$ then $H 0$ rejected which mean there is relation of work load with nurses work stress in ICU Room dr. H. Moh Anwar Sumenep.

Efforts to suppress the work stress of nurses ICU dr. H. Moh.AnwarSumenep done by applying a service system in favor of nurses. Nurses should also enjoy the world of work and try to create a conducive working

environment.

Keywords: Workload, work stress, ICU nurse

\section{PENDAHULUAN}

Intensive Care Unit (ICU) adalah bagian dari rumah sakit yang mandiri, dengan staf yang khusus dan perlengkapan yang khusus ditujukan untuk observasi, perawatan dan tetapi pasien- pasien yang menderita penyakit akut, cedera atau penyulit-penyulit yang mengancam nyawa atau potensial mengancam nyawa. Kegiatan keperawatan yang dilakukan di Ruang ICU meliputi penilaian terhadap kondisi yang mengancam jiwa, deteksi awal terjadinya tanda dan gejala resiko komplikasi atau penyulit, perawatan pasien dengan kondisi kritis akut yang memerlukan tindakan segera (life saving) atau pasien kritis dengan kondisi sakit kronik, pemantauan hemodinamik secara terus menerus setiap jam, interpretasi dan intervensi tes diagnostik yang dilakukan kepada pasien.

Pemberian terapi sesuai dengan program terapi dan tindakan-tindakan lainnya. Dinamika perawatan ICU yang kompleks dan kondisi pasien kritis inilah yang sering memicu terjadinya stresor terjadinya stres di ICU (Hudak \& Gallo, 2010).
Stres merupakan beban kerja yang berlebihan, perasaan susah dan ketegangan emosional yang menghambat performance individu (Robbins, 2004 dalam Almasitoh, 2011). Stres kerja berhubungan dengan kondisi kerja dan kesehatan fisik perawat (Gelsema et al., 2006). Stres dapat diakibatkan oleh bermacam-macam hal, termasuk dari tugas pokok perawat dan tanggung jawab, beban kerja yang berat, jenis kepemimpinan (Clegg et al., 2001), kepuasan kerja yang rendah (Gelsema et al., 2006), ketidakjelasan peraturan (Gray-Toft \& Anderson, 1981; Piko, 2006), pengalaman kerja yang kurang (Sadovich, 2005), dan dukungan sosial yang rendah (Gelsema et al., 2006).

Stres yang berlangsung lama dan terjadi terus-menerus dalam intensitas yang tinggi mengakibatkan kelelahan fisik dan mental yang disebut burn out. Burn out merupakan salah satu bentuk stres yang sering dialami oleh pekerja yang berhubungan dengan pelayanan jasa masyarakat atau public service (Maslach, 1991 dalam Suryaningrum, 2015). Stres kerja yang dialami 
perawat dapat mengganggu kinerja dan mengurangi produktivitas perawat dalam memberikan pelayanan kepada pasien. Perawat yang mengalami stres menjadi nervous dan merasakan kekhawatiran kronis. Mereka sering menjadi marah-marah, agresif, tidak dapat relaks, atau memperlihatkan sikap yang tidak kooperatif (Hasibuan, 2009)

Penelitian yang dilakukan Haryanti, dkk., (2013) tentang hubungan antara beban kerja dengan stres kerja perawat di Instalasi Gawat Darurat RSUD Kabupaten Semarang diperoleh hasil sebagian besar perawat mengalami stres sedang sebanyak 24 responden $(82,8 \%)$ dan stres ringan pada 5 responden (17,2\%). BOR di Ruang ICU RSUD dr. H. Moh. Anwar Sumenep selama bulan Oktober sampai dengan Desember 2016, bulan Oktober 2016 sebesar 89,5\%, bulan November 2016 sebesar 90,4\%, dan bulan Desember 2016 sebesar 88,7\%.

Berdasarkan hasil wawancara dengan 5 perawat di Ruang ICU RSUD dr. H. Moh. Anwar Sumenep pada 10 Desember 2016, tugas pokok perawat ICU antara lain melaksanakan pengkajian perawatan kritis, melaksanakan analisis data untuk merumuskan diagnosis keperawatan, merencanakan dan melaksanakan tindakan, mendokumentasian askep, melaksanakan sistem kerja yang terbagi atas tiga waktu yaitu shift pagi, shift sore dan shift malam, memelihara peralatan keperawatan dan medis agar selalu dalam keadaan siap pakai, melakukan pre serta post conference dan serah terima pasien pada saat pergantian dinas. Sebanyak 4 orang perawat merasakan intensitas kerja yang tinggi terutama saat menangani pasien kritis sehingga mudah mengalami stres dan berimbas pada pelaksanaan tugas yang tidak maksimal. Gejala stres yang sering dialami adalah sering pusing, lelah, bosan, dan konsentrasi yang mudah terganggu.

Menurut Manuaba (2000) dalam Suryaningrum (2015), beban kerja dapat berupa tuntutan tugas atau pekerjaan, organisasi dan lingkungan kerja. Beban kerja perawat di tempat pelayanan kesehatan meliputi beban kerja fisik dan mental. Beban kerja fisik seperti mengangkat pasien, memandikan pasien, membantu pasien ke kamar mandi, dan segala bantuan yang bersinggungan dengan aktivitas fisik. Beban kerja mental dapat berupa bekerja dengan sistem shift, menjaga komunikasi yang baik dengan perawat lain, atasan, pasien dan juga keluarga pasien, dan tanggung jawab terhadap kesembuhan pasien. Beban kerja meliputi dua aspek yaitu jumlah pekerjaan, kecepatan dan ketepatan. Jumlah beban kerja berlebih dan beban kerja terlalu sedikit merupakan pembangkit stress (Jex dalam Kumalasari, 2014). Perawat harus mengerjakan pekerjaan dengan jumlah beban yang bervariasi tergantung jenis tanggung jawab yang dibebankan. Kecepatan dan ketepatan dalam melakukan pekerjaan berkaitan dengan waktu yang tersedia. Perawat dituntut untuk bekerja dengan cepat dan tepat dalam menangani pasien yang sedang kritis.

Semakin cepat pekerjaan harus dikerjakan, semakin tinggi tingkat stres kerja.

Manajemen Rumah sakit harus memperhatikan stres kerja yang dialami perawat. Hal tersebut dimaksudkan untuk menjaga kualitas pelayanan rumah sakit agar selalu optimal dan jauh dari kritik negatif. Dari permasalahan di atas, perlu diadakan penelitian yang menganalisis mengenai hubungan beban kerja dengan stres kerja perawat. Penelitian ini dimaksudkan untuk dapat berkontribusi dalam mengatasi stres kerja perawat, dengan judul penelitian "hubungan beban kerja dengan stres kerja pada perawat di Ruang ICU RSUD dr. H. Moh. Anwar Sumenep".

\section{METODE PENELITIAN}

Penelitian ini menggunakan desain analitik dengan pendekatan Cross Sectional populasi dalam penelitian ini adalah Semua perawat di Ruang ICU RSUD dr. H. Moh. Anwar Sumenep sebanyak 17 orang.Sampel dalam penelitian berjumlah 17 orang yang memenuhi kriteria inklusi.

Variabel independen dalam penelitian ini adalah beban kerja perawat. Variable dependennya adalah stress kerja perawat. Instrumen yang digunakan adalah kuesioner dan lembar observasi. Analisa data diolah secara deskriptif dan statistik analitik. Secara statistik analitik menggunakan uji statistik Spearman dengan signifikansi 0,05.

\section{HASIL PENELITIAN}

1. Karakteristik Responden

\begin{tabular}{ccc}
\hline Karakteristik & $\mathbf{f}$ & $\%$ \\
\hline Umur & & \\
20-30 tahun & 3 & $17,6 \%$ \\
$31-40$ tahun & 12 & $70,6 \%$ \\
41-50 tahun & 2 & $11,8 \%$ \\
Total & 17 & $100 \%$ \\
\hline
\end{tabular}




\begin{tabular}{ccc}
\hline Jenis kelamin & $\mathbf{F}$ & $\%$ \\
\hline Laki-Laki & 9 & $52,9 \%$ \\
Perempuan & 8 & $47,1 \%$ \\
Total & 17 & $100 \%$ \\
\hline Lama Kerja & $\mathbf{F}$ & $\%$ \\
\hline 5-10 tahun & 6 & $35,3 \%$ \\
10-15 tahun & 9 & $52,9 \%$ \\
$>15$ tahun & 2 & $11,8 \%$ \\
Total & 17 & $100 \%$ \\
\hline
\end{tabular}

\begin{tabular}{|c|c|c|}
\hline Pendidikan & $\mathbf{F}$ & $\%$ \\
\hline $\begin{array}{c}\text { DIII } \\
\text { S1 Ners } \\
\end{array}$ & $\begin{array}{l}12 \\
5 \\
\end{array}$ & $\begin{array}{l}70,6 \% \\
29,4 \% \\
\end{array}$ \\
\hline Total & 17 & $100 \%$ \\
\hline
\end{tabular}
sebagian besar responden berjenis kelamin laki-laki, yaitu sebanyak 9 responden $(57,1 \%)$. sebagian besar responden berumur 31-40 tahun, yaitu sebanyak 12 responden (70,6\%) dan sebagian besar responden berpendidikan D-III, yaitu sebanyak 12 responden $(70,6 \%)$ serta sebagian besar lama kerja responden adalah 10-15 tahun, yaitu sebanyak 9 responden $(52,9 \%)$.

Tabel 2 Distribusi Beban Kerja Perawat di RuangICU RSUDdr. H.Moh Anwar Sumenep

\begin{tabular}{ccc}
\hline BebanKerja & $\mathrm{F}$ & $\%$ \\
\hline Ringan & 4 & 23,5 \\
Sedang & 9 & 52,9 \\
Berat & 4 & 23,5 \\
Total & 17 & 100
\end{tabular}

Tabel 2 menunjukkan bahwa sebagian besar beban kerja perawat di Ruang ICU RSUD dr.H. Moh Anwar Sumenep adalah sedang,yaitu sebanyak 9 responden $(52,9 \%)$.

Tabel 3 Distribusi Stres Kerja Perawat diRuang ICU RSUD dr. H. Moh Anwar Sumenep

\begin{tabular}{ccc}
\hline Stress Kerja & $\mathrm{F}$ & $\%$ \\
\hline Ringan & 10 & 58,8 \\
Sedang & 7 & 41,2 \\
Berat & 0 & 0 \\
\hline Total & 17 & 100 \\
\hline
\end{tabular}

Tabel 3 menunjukkan bahwa sebagian besar stress kerja perawat di Ruang ICU RSUD dr.H. Moh Anwar Sumenep adalah ringan,yaitu sebanyak 10 responden $(58,8 \%)$.

Tabel 4. Tabulasi Silang Karakteristik Responden dengan Beban Kerja Perawat di Ruang ICU RSUD dr. H. Moh Anwar Sumenep

4.1 Tabulasi Silang jenis Kelamin dengan Beban Kerja

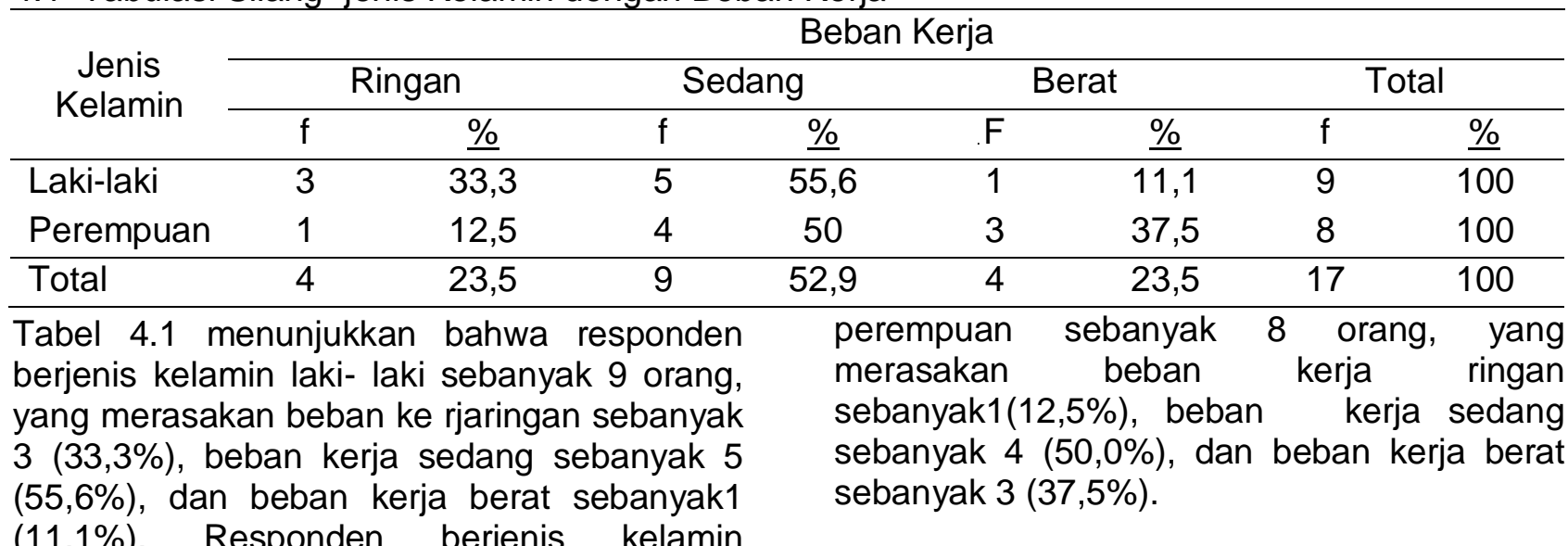

$(11,1 \%)$. Responden berjenis kelamin 4.2 Tabulasi Silang Umur dengan Beban Kerja

\begin{tabular}{|c|c|c|c|c|c|c|c|c|}
\hline \multirow{3}{*}{ Umur } & \multicolumn{8}{|c|}{ Beban Kerja } \\
\hline & \multicolumn{2}{|c|}{ Ringan } & \multicolumn{2}{|c|}{ Sedang } & \multicolumn{2}{|c|}{ Berat } & \multicolumn{2}{|c|}{ Total } \\
\hline & $f$ & $\%$ & $f$ & $\%$ & $f$ & $\%$ & $f$ & $\%$ \\
\hline 20-30 tahun & 0 & 0 & 3 & 100 & 0 & 0 & 3 & 100 \\
\hline $31-40$ tahun & 2 & 16,7 & 6 & 50 & 4 & 33,3 & 12 & 100 \\
\hline 41-50 tahun & 2 & 100 & 0 & 0 & 0 & 0 & 2 & 100 \\
\hline Total tahun & 4 & 23,5 & 9 & 52,9 & 4 & 23,5 & 17 & 100 \\
\hline \multicolumn{4}{|c|}{$\begin{array}{l}\text { Tabel } 4.2 \text { menunjukkan bahwa responden } \\
\text { berumur } 20-30 \text { tahun sebanyak } 3 \text { orang, yang } \\
\text { seluruhnya merasakan beban kerja sedang } \\
\text { sebanyak } 3(100,0 \%) \text {. Responden berumur } \\
31-40 \text { tahun sebanyak } 12 \text { orang, yang } \\
\text { merasakan beban kerja ringan sebanyak }\end{array}$} & \multicolumn{5}{|c|}{$\begin{array}{l}2(16,7 \%) \text {, beban kerja sedang sebanyak } \\
(50,0 \%) \text {,dan beban kerja berat sebanyak } \\
(33,3 \%) \text {. Responden berumur } 41-50 \text { tahu } \\
\text { sebanyak } 2 \text { orang,yang seluruhny } \\
\text { merasakan beban kerjaringan sebanyak } \\
(100,0 \%) \text {. }\end{array}$} \\
\hline
\end{tabular}


4.3 Tabulasi Silang Pendidikan dengan Beban Kerja

\begin{tabular}{ccccccccc}
\hline & \multicolumn{8}{c}{ Beban Kerja } \\
\cline { 2 - 9 } Pendidikan & \multicolumn{2}{c}{ Ringan } & \multicolumn{2}{c}{ Sedang } & \multicolumn{3}{c}{ Berat } & \multicolumn{2}{c}{ Total } \\
\cline { 2 - 9 } & $\mathrm{F}$ & $\%$ & $\mathrm{f}$ & $\%$ & $\mathrm{~F}$ & $\%$ & $\mathrm{f}$ & $\%$ \\
\hline DIII & 1 & 8,3 & 7 & 58,3 & 4 & 33,3 & 12 & 100 \\
S1 Ners & 3 & 60 & 2 & 40 & 0 & 0 & 5 & 100 \\
\hline Total & 4 & 23,5 & 9 & 52,9 & 4 & 23,5 & 17 & 100 \\
\hline
\end{tabular}

Tabel 4.3 menunjukkan bahwa responden berpendidikan D-III sebanyak 12 orang yang merasakan beban kerja ringan sebanyak1 $(8,3 \%)$, beban kerja sedang sebanyak7 $(58,3 \%)$,dan beban kerja berat sebanyak 4

(33,3\%). Responden berpendidikan S1 Ners
sebanyak 5 orang, yang merasakan beban kerja ringan sebanyak $3(60,0 \%)$ dan beban kerja sedang sebanyak $2(40,0 \%)$.

4. 4 Tabulasi Silang Lama Kerja dengan Beban Kerja

\begin{tabular}{|c|c|c|c|c|c|c|c|c|}
\hline \multirow{2}{*}{$\begin{array}{c}\text { Lama } \\
\text { Kerja } \\
\text { (Tahun) }\end{array}$} & \multicolumn{8}{|c|}{ Beban Kerja } \\
\hline & \multicolumn{2}{|c|}{ Ringan } & \multicolumn{2}{|c|}{ Sedang } & \multicolumn{2}{|c|}{ Berat } & \multicolumn{2}{|c|}{ Total } \\
\hline & $f$ & \% & $F$ & \% & $f$ & $\%$ & $f$ & $\%$ \\
\hline 05-Okt & 0 & 0 & 4 & 66,7 & 2 & 33,3 & 6 & 100 \\
\hline Okt-15 & 2 & 22,2 & 5 & 55,6 & 2 & 22,2 & 9 & 100 \\
\hline$>15$ & 2 & 100 & 0 & 0 & 0 & 0 & 2 & 100 \\
\hline Total & 4 & 23,5 & 9 & 52,9 & 4 & 23,5 & 17 & 100 \\
\hline
\end{tabular}

Tabel 4.4 menunjukkan bahwa responden (22,2\%), beban kerja sedang sebanyak 5 dengan lama kerja 510 tahun sebanyak 6 orang yang merasakan beban kerja sedang sebanyak $4(66,7 \%)$ dan beban kerja berat sebanyak 2 (33,3\%). Responden dengan lama kerja10-15 tahun sebanyak 9 orang,yang merasakan beban kerja ringan sebanyak 2

$(55,6 \%)$, dan beban kerja berat sebanyak 2 $(22,2 \%)$. Responden dengan lama kerja $>15$ tahun sebanyak 2 orang,yang seluruhnya merasakan bebankerjaringan sebanyak 2 $(100,0 \%)$.

5. Tabulasi Silang Karakteristik Responden dengan Stres Kerja Perawat di Ruang ICU RSUDdr. H. Moh Anwar Sumenep

5.1 Tabulasi Silang Jenis Kelamin dengan Stres Kerja

\begin{tabular}{ccccccc}
\hline \multirow{2}{*}{ Jenis Kelamin } & \multicolumn{3}{c}{ Beban Kerja } \\
\cline { 2 - 7 } & $\mathrm{f}$ & $\%$ & $\mathrm{~F}$ & $\%$ & $\mathrm{f}$ & $\%$ \\
\cline { 2 - 7 } & 6 & 66,7 & 3 & 33,3 & 9 & 100 \\
Laki-laki & 4 & 50 & 4 & 50 & 8 & 100 \\
\hline Perempuan & 10 & 58,8 & 7 & 41,2 & 17 & 100 \\
\hline Total & & & \multicolumn{2}{c}{ Sedang }
\end{tabular}

Tabel 5.1menunjukkan bahwa responden berjenis kelamin laki- laki sebanyak 9 orang, yang mengalami stres kerja ringan sebanyak $6(66,7 \%)$ dan stres kerja sedang sebanyak 3 (33,3\%). Responden berjenis kelamin perempuan sebanyak 8orang, masing-masing mengalami stres kerja ringan dan sedang sebanyak $4(50,0 \%)$.

5.2 Tabulasi Silang Umur dengan Stres Kerja

\section{Beban Kerja}

\begin{tabular}{ccccccc} 
& \multirow{2}{*}{ Umur } & \multicolumn{2}{c}{ Ringan } & \multicolumn{2}{c}{ Sedang } & \multicolumn{2}{c}{ Total } \\
\cline { 2 - 7 } & $\mathrm{F}$ & $\%$ & $\mathrm{~F}$ & $\%$ & $\mathrm{~F}$ & $\%$ \\
\hline $20-30$ & 2 & 66,7 & 1 & 33,3 & 3 & 100 \\
$31-40$ & 6 & 50 & 6 & 50 & 12 & 100 \\
$41-50$ & 2 & 100 & 0 & 0 & 2 & 100 \\
\hline Total & 10 & 58,8 & 7 & 41,2 & 17 & 100
\end{tabular}

Tabel 5.2 menunjukkan bahwa responden berumur 20-30 tahun sebanyak 3 orang,yang

mengalami stres kerja ringan sebanyak 2 $(66,7 \%)$ dan stres kerja sedang 
sebanyak1(33,3\%). Responde nberumur 3140 tahun sebanyak 12 orang, masing-masing mengalami stres kerja ringan dan sedang sebanyak 6 (50,0\%). Responden berumur 415.3 Tabulasi Silang Pendidikan dengan Stres Kerja
50 tahun sebanyak 2 orang,yang seluruhnya mengalami stres kerja ringan sebanyak 2 $(100,0 \%)$

\begin{tabular}{ccccccc}
\hline \multirow{2}{*}{ Pendidikan } & \multicolumn{2}{c}{ Stres Kerja } \\
\cline { 2 - 7 } & \multicolumn{2}{c}{ Ringan } & \multicolumn{2}{c}{ Sedang } & \multicolumn{3}{c}{ Total } \\
& $\mathrm{f}$ & $\%$ & $\mathrm{f}$ & $\%$ & $\mathrm{f}$ & $\%$ \\
\hline DIII & 5 & 41,7 & 7 & 58,3 & 12 & 100 \\
S1 Ners & 5 & 100 & 0 & 0 & 5 & 100 \\
\hline Total & 10 & 58,8 & 7 & 41,2 & 17 & 100 \\
\hline
\end{tabular}

Tabel 5.3 menunjukkan bahwa responden berpendidikan D-III sebanyak 12 orang yang mengalami stres kerja ringan sebanyak 5 $(41,7 \%)$ dan stress kerja sedang sebanyak 7 (58,3\%). Responden berpendidikan S1 Ners sebanyak 5 orang yang seluruhnya mengalami stres kerja ringan sebanyak 5 $(100,0 \%)$.

5.4Tabulasi Silang Lama Kerja dengan Stres Kerja, Tabel 5.4 Tabulasi Silang Lama Kerja dengan Stres Kerja

\begin{tabular}{|c|c|c|c|c|c|c|}
\hline \multicolumn{7}{|c|}{ stres kerja } \\
\hline \multirow[t]{2}{*}{ lama kerja } & \multicolumn{2}{|c|}{ Ringan } & \multicolumn{2}{|c|}{ sedang } & \multicolumn{2}{|c|}{ Total } \\
\hline & $\mathrm{F}$ & $\%$ & $\mathrm{~F}$ & $\%$ & & \\
\hline 5-10 tahun & 3 & 50 & 3 & 50 & 6 & 100 \\
\hline $10-15$ tahun & 5 & 55,6 & 4 & 44,4 & 9 & 100 \\
\hline
\end{tabular}

Tabel 5.4 menunjukkan bahwa responden dengan lama kerja 5-10 tahun sebanyak 6orang, masing-masing mengalami stres kerja ringan dan sedang sebanyak $3(50,0 \%)$. Responden dengan lama kerja 10-15 tahun sebanyak 9 orang,yang mengalami stres kerja ringan sebanyak $5(55,6 \%)$ dan stres kerja sedang sebanyak 4(44,4\%). Responden dengan lama kerja $>15$ tahun sebanyak 2 orang, yang seluruhnya mengalami stres kerjaringan sebanyak $2(100,0 \%)$.

5.5 Tabulasi Silang Beban Kerja dengan Stres Kerja Perawat di Ruang ICU RSUD dr. H. Moh Anwar Sumenep

\begin{tabular}{ccccccc}
\hline \multirow{2}{*}{ Beban Kerja } & \multicolumn{2}{c}{ Ringan } & \multicolumn{2}{c}{ Sedang } & \multicolumn{2}{c}{ Total } \\
\cline { 2 - 7 } & $\mathrm{f}$ & $\%$ & $\mathrm{~F}$ & $\%$ & $\mathrm{f}$ & $\%$ \\
\hline Ringan & 4 & 100 & 0 & 0 & 4 & 100 \\
Sedang & 5 & 55,6 & 4 & 44,4 & 9 & 100 \\
Berat & 1 & 25 & 3 & 75 & 4 & 100 \\
\hline Total & 10 & 58,8 & 7 & 42,2 & 17 & 100
\end{tabular}

Tabel 5.15 menunjukkan bahwa responden dengan beban kerja ringan sebanyak 4 orang, danseluruhnya mengalami stres ringan sebanyak 14 (100,0\%). Responden dengan beban kerja sedang sebanyak 9 orang,yang mengalami stres ringan sebanyak $5(55,6 \%)$ dan yang mengalami stres sedang sebanyak 4 (44,4\%). Responden dengan beban kerja berat sebanyak 4 orang, yang mengalami stres ringan sebanyak $1(25,0 \%)$ dan yang mengalami stres sedang sebanyak $3(75,0 \%)$. Hasil analisa data Spearman diperoleh $p$ value $=0,031$ dengan nilai $\alpha=0,05$, jadi $p$ $(0,031)<\alpha \quad(0,05)$ maka HO ditolak yang berarti ada hubungan beban kerja dengan stres kerja perawat di Ruang ICU RSUD dr. H. Moh Anwar Sumenep.

\section{PEMBAHASAN}

Everly dkk. (dalam Prihatini, 2007) mengatakan bahwa beban kerja adalah keadaan dimana pekerja dihadapkan pada tugas yang harus diselesaikan pada waktu tertentu. Kategori lain dari beban kerja adalah kombinasi dari beban kerja kuantitatif dan kualitatif. Beban kerja secara kuantitatif timbul karena tugas-tugas terlalu banyak atau sedikit, sedangkan beban kerja kualitatif jika pekerja merasa tidak mampu melakukan tugas atau melakukan tugas tidak menggunakan ketrampilan atau potensi dari pekerja.

Dalam penelitian ini, beban kerja perawat dinilai dari dua indikator, tindakan produktif dan non produktif perawat. Tindakan 
produktif berdasarkan observasi atau pengukuran terhadap tindakan keperawatan langsung dan tidak langsung. Sedangkan tindakan non produktif berdasarkan pengukuran terhadap kegiatan non produktif perawat. Beban kerja perawat di ruang ICU RSUD dr. H. Moh. Anwar Sumenep disinyalir dampak dari tuntutan pelayanan keperawatan ekstra ketat dan cepat untuk mempertahankan kondisi dan menyelamatkan nyawa pasien. Selain itu dengan pemantauan dan pencatatan kondisi pasien secara rutin dan berkesinambungan juga merupakan beban tersendiri. Secara psikologis ada beban untuk dapat mempertahankan kondisi pasien supaya tidak tambahmemburuk. Perawat juga biasanya merasa terbebani untuk selalu menyampaikan segala kondisi pasien secara jujur.

Beban kerja yang tinggi di Ruang ICU RSUD dr. H. Moh. Anwar Sumenep akan menimbulkan kelelahan baik fisik atau mental dan reaksi-reaksi emosional seperti sakit kepala, gangguan pencernaan dan mudah marah. Sedangkan pada beban kerja yang ringan dimana pekerjaan yang terjadi karena pengulangan gerak akan menimbulkan kebosanan, rasa monoton. Kebosanan dalam kerja rutin sehari- hari karena tugas atau pekerjaan yang terlalu sedikit mengakibatkan kurangnya perhatian pada pekerjaan sehingga secara potensial membahayakan pekerja.

Bekerja di ruang RSUD dr. H. Moh. Anwar Sumenep dalam setiap kesempatan akan menemui pasien yang memiliki karakteristik yang bervariasi yang berdampak pada kondisi dan beban kerja yang berbeda. Untuk itu perawat harus peran sebagai tenaga serba bisa, memiliki inisiatif, berperilaku kreatif serta memiliki wawasan yang luas dengan motivasi kerja keras, cerdas, iklas dan kerja berkualitas. ICU merupakan salah satu lingkungan kerja yang memiliki kecenderungan stres yang tinggi (Emanuelsen \& Rosenlicht, 2000). Menurut Highley dalam Cox (1996) dalam Haryanti dkk. (2013), perawat juga secara alamiah merupakan profesi yang penuh dengan stres, berdasarkan hasil observasinya didapatkan bahwa setiap hari perawat berhadapan dengan penderita yang kaku, duka cita dan kematian, banyak tugas-tugas perawat tidak diberi penghargaan, tidak menyenangkan dan penuh tekanan, sering diremehkan, menakutkan. Stres kerja perawat juga dapat terjadi karena jumlah tindakan yang harus diselesaikan tidak sebanding dengan jumlah tenaga perawat yang ada.

Stres perawat ICU RSUD dr. H. Moh. Anwar Sumenep bentuk tanggapan menyeluruh dari tubuh baik fisik maupun mental terhadap setiap tuntutan ataupun perubahan yang mengganggu, mengancam rasa aman dan harga diri. stres perawat juga bersifat pengalaman pribadi dan subjektif. Perawat ICU RSUD dr. H. Moh. Anwar Sumenep dihadapkan pada pasien dengan kondisi jiwa yang terancam, sehingga membutuhkan perhatian yang khusus selama 24 jam/hari. Kondisi ini memerlukan energi fisik yang lebih besar dengan asuhan keperawatan yang khusus pula. Selain itu pasien kritis menuntut kecepatan dan ketepatan melakukan tindakan yang tidak selalu dibutuhkan pada situasi keperawatan lain.

Perawat yang bertugas di ICU melaksanakan 3 (tiga) tugas utama yaitu life support, memonitor keadaan pasien dan mencegah komplikasi yang mungkin terjadi (Tabrani Rab, 2007). Dengan dilengkapi berbagai fasilitas canggih yang berada di ruang ICU RSUD dr. H. Moh. Anwar Sumenep seperti monitor jantung, fibrilator, dsb menuntut keterampilan khusus dengan perawat-perawat yang terlatih dalam mengoperasikannya. Pasien kritis ICU RSUD dr. H. Moh. Anwar Sumenep mengalami masalah gangguan fungsi yang rumit dan kompleks sehingga memerlukan penatalaksanaan khusus. Hal ini dapat menimbulkan stres bagi keluarga. Keluarga sering mengeluh dan melakukan kritikan kepada perawat. Kondisi ini dapat pula menimbulkan stres bagi perawat sehingga menghambat pelaksanaan asuhan keperawatan yang diberikan pada pasien .

Apabila stres mencapai titik puncak yang kira-kira sesuai dengan kemampuan maksimum kinerja perawat maka pada titik ini stres tambahan cenderung tidak menghasilkan perbaikan kinerja. Selanjutnya bila stres yang dialami perawat terlalu besar, maka kinerja akan mulai menurun, karena stres tersebut mengganggu pelaksanaan kerja perawat dan akan kehilangan kemampuan untuk mengendalika atau menjadi tidak mampu untuk mengambil keputusan dan perilaku menjadi tidak menentu. Akibat yang paling ekstrim adalah kinerja menjadi nol, perawat mengalami gangguan, menjadi sakit, dan tidak kuat lagi untuk bekerja, 
menjadi putus asa, keluar atau menolak bekerja.

Dari hasil penelitian menunjukkan bahwa responden dengan beban kerja ringan sebanyak 4 orang, dan seluruhnya mengalami stres ringan sebanyak $14 \quad(100,0 \%)$. Responden dengan beban kerja sedang sebanyak 9 orang, yang mengalami stres ringan sebanyak $5 \quad(55,6 \%)$ dan yang mengalami stres sedang sebanyak $4(44,4 \%)$. Responden dengan beban kerja berat sebanyak 4 orang, yang mengalami stres ringan sebanyak $1 \quad(25,0 \%)$ dan yang mengalami stres sedang sebanyak $3(75,0 \%)$. Hasil analisa data Spearman diperoleh $p$ value $=0,031$ dengan nilai $\alpha=0,05$, jadi $p$ $(0,031)<\alpha \quad(0,05)$ maka HO ditolak yang berarti ada hubungan beban kerja dengan stres kerja perawat di Ruang ICU RSUD dr. H. Moh Anwar

Sumenep.

Penelitian yang dilakukan Haryanti dkk. (2013), tentangHubungan antara Beban Kerja dengan Stres Kerja Perawat di Instalasi Gawat Darurat RSUD Kabupaten Semarang diperoleh hasil analisis statistik menggunakan uji Kendall Tau's didapatkan nilai p 0,000, artinya terdapat hubungan antara beban kerja dengan stres kerja perawat di RSUD Kabupaten Semarang. Nilai $r$ sebesar 0,751 pada hasil uji memiliki arti 1) hubungan antara beban kerja dengan stres kerja memiliki hubungan dalam kategori kuat, 2) arah hubungan adalah positif, artinya semakin meningkat beban kerja akan semakin menyebabkan stres.

Stres kerja perawat dapat terjadi apabila perawat dalam bertugas mendapatkan beban kerja yang melebihi kemampuan sehingga perawat tidak mampu memenuhi atau menyelesaikan tugasnya. Manifestasi dari stres kerja perawat antara lain akibat karakterisasi pasien, pengkajian terhadap pasien, dan aspek lingkungan kerja yang mengganggu merupakan langkah awal dalam menangani masalah-masalah yang datang mengenai tingkat kepadatan ruangan emergency, efisiensi pelaksanaan tugas, serta adanya tuntutan untuk menyelamatkan pasien.

Upaya menekan stres kerja perawat ICU RSUD dr. H. Moha Anwar Sumenep dilakukan dengan menerapkan sistem pelayanan yang berpihak pada perawat misalnya pada Nurse Station didesain senyaman mungkin seperti suasan rumah sehingga perawat betah berlama-lam di tempat kerja. Selain itu, perawat harus lebih menikmati dunia kerja dan berusaha menciptakan lingkungan kerja kondusif dengan menganggap bahwa profesi perawat bukan hanya labelisasi duniawi melainkan juga amaliah.

\section{Simpulan}

Sebagian besar beban kerja perawat di Ruang ICU RSUD dr. $\mathrm{H}$. Moh Anwar Sumenep adalah sedang. Sebagian besar stress kerja perawat di Ruang ICU RSUD dr. $\mathrm{H}$. Moh Anwar Sumenep adalah ringan. Ada hubungan beban kerja dengan stres kerja perawat di Ruang ICU RSUD dr. H. Moh Anwar Sumenep.

\section{Saran}

Perawat harus lebih menikmati dunia kerja dan berusaha menciptakan lingkungan kerja kondusif dengan menganggap bahwa profesi perawat bukan hanya labelisasi duniawi melainkan juga amaliah.Masyarakat juga dapat membantu meringankan beban dan stres kerja perawat untuk menciptakan suasana kondusif dengan tidak memaksakan kehendak dan lebih sadar dan sabar saat meminta serta mendapat pelayanan kesehatan di Ruang ICU RSUD dr. H. Moh. Anwar Sumenep. Penelitian dengan desain eksperimental tentang beban dan stres kerja perawat diperlukan untuk menentukan nilai presisi hubungan sebab akibat antara keduanya, sehingga dapat mengatasi permasalahan perawat di tempat kerja.

\section{KEPUSTAKAAN}

Almasitoh, Ummu Hany. (2011). Stres Kerja Ditinjau dari Konflik Peran Ganda dan Dukungan Sosial pada Perawat. Jurnal Psikologi Islam (JPI). Lembaga Penelitian Pengembangan dan Keislaman (LP3K). Vol. 8 No. 1.

American Association of Critical Care Nurse. (2008). AACN Scope and standards for acute and critical care nursing practice. Columbia: AACN.

Ambarwati, Diah. (2014). Pengaruh Beban Kerja terhadap Stres Perawat IGD dengan Dukungan Sosial sebagai Variabel Moderating (Studi pada RSUP Dr. Kariadi Semarang). Universitas Diponegoro Semarang.

Anoraga, P. (2001). Psikologi Kerja. Jakarta: Rineka Cipta.

Depkes RI. (2006). Direktorat Keperawatan dan Keteknisan Direktorat Jendral 
Pelayanan Medik. Standar pelayanan keperawatan di ICU. Jakarta: Depkes RI.

Dharma, Kusuma Kalana. (2011). Metodologi Penelitian Keperwatan: Panduan Melaksanakan dan Menerapkan Hasil Penelitian. Jakarta: Trans Infomedia.

Dwijayanti, W. (2010). Stres kerja pada perawat pelaksana di ruang rawat inap RS Krakatau Medika tahun 2010. Jakarta: Fakultas Kesehatan Masyarakat Universitas Indonesia.

Gelsema, T. I., Van Der Doef, M., Maes, S., Janssen, M., \& Akerboom, S. (2006).A Longitudinal study of Job stres in the nursing profession: Causes and consequences. Journal of Nursing Management. 14.

Gray-Toft, P., Anderson, J. G. (1981). Stres among hospital nursing staff: Its causes and effects. Social Science Medicine. 15A.

Hasibuan, Malayu S.P. (2009). Manajemen Sumber Daya Manusia. Jakarta: BumiAksara.

Haryanti, dkk. (2013). Hubungan antara Beban Kerja dengan Stres Kerja Perawat di Instalasi Gawat Darurat RSUD Kabupaten Semarang. Jurnal Managemen Keperawatan . Volume 1, No. 1.

Hudak, C. M. \& Gallo, B. M. (2010). Keperawatan kritis: pendekatan holistic volume 1 (Ed. 6). (M. Ester, Editor) (Asih, Penerjemah). Jakarta: EGC.

llyas, Yaslis. (2000). Perencanaan Sumber Daya Manusia Rumah Sakit. UGM. KEPMENKES No 1778/MENKES/SK/XII/2010 tentang pedomanpenyelenggaraan pelayanan Intencive Care Unit (ICU) di Rumah Sakit.

Looker, T. \& Gregson, O. (2005). Managing Stress. Jakarta: Penerbit Baca.

Munandar, A. S. (2001). Stres dan Keselamatan Kerja "Psikologi Industri danOrganisasi. Penerbit Universitas Indonesia.

Muthmainah, lin. (2012). Faktor-faktor Penyebab Stres Kerja di Ruangan ICU Pelayanan Jantung Terpadu dr. Cipto Mangunkusumo Jakarta. Fakultas IImu Keperawatan Program Sarjana Keperawatan depok.l
NIOSH. (2008). Exposure to Stress Occupational Hazards in Hospital. $\mathrm{NIOSH}$.

Notoatmodjo, Soekidjo. (2010). Promosi Kesehatan dan Perilaku Kesehatan.Jakarta: Rineka Cipta.

Nursalam. (2016). Metodologi Penelitian IImu Keperawatan, edisi 4. Jakarta: Salemba medika.

Prihatini, Lilis Dian. (2007). Analisis Hubungan Beban Kerja dengan Stres Kerja Perawat di Tiap Ruang Rawat Inap RSUD Sidikalang. Universitas Sumatera Utara.

Potter, P. A. \& Perry, A.G. (2005). Buku Ajar Fundamental Keperawatan (Vol.1). (Y. Asih, M. Sumarwati, D. Efriyani, \& dkk., Penerjemah). Jakarta: EGC.

Rahmaniaty (2010). Analisis faktor-faktor yang berhubungan dengan stres kerja karyawan di bidang ekam medik RS kanker "Dharmais" tahun 2010. Jakarta: Fakultas IImu Keperawatan Universitas Indonesia.

Salmawati, Lusia. (2014). Pengaruh Penerapan Sistem Manajemen Keselamatan dan Kesehatan Kerja dengan Motivasi Kerja dan Stres Kerja pada Perawat di RSU Anutapura Palu. UGM, Yogyakarta.

Sadovich, J. M. (2005). Work excitement in nursing: An examination of the relationship between work excitement and burnout. Nursing Economics.

Schultz, D., Schultz, S.E. (2006). Phschology Work Today (9 Edition). NewJersey: Pearson Education, Inc.

Siagian, P. Sondang. (2014). Manajemen Sumber Daya Manusia. Jakarta: BumiAksara.

Siboro, T. S. (2009). Hubungan kondisi kerja dan karakteristik individu dengan stres kerja pad pegawai lembaga pemasyarakatan kelas II B lubuk pakam2008. Fakultas IImu Keperawatan Universitas Sumatra Utara.

Suryaningrum, Tri. (2015). Pengaruh Beban Kerja dan Dukungan Sosial terhadap Stres Kerja pada Perawat RS PKU Muhammadiyah Yogyakarta. Program Studi Manajemen Jurusan Manajemen Fakultas Ekonomi Universitas Negeri Yogyakarta

Tarwaka., Bakri, A., Sudiajeng, L. (2004). Ergonomi, Untuk Keselamatan, 
Kesehatan Kerja dan Produktivitas. Zulfan, Y. (2012). Psikologi Keperawatan. UNIBA Press, Surakarta. Jakarta: PT Raja Grafindo Persada

Waluyo, M. (2009). Psikologi teknik industri. Jakarta: Graha IImu. 